\title{
Effects of Rice Bran Fiber on Changes in the Quality Characteristics of Raw Ground Pork during Chilled Storage
}

\author{
Hyun-Wook Kim, Yun-Sang Choi ${ }^{1}$, Ji-Hun Choi ${ }^{1}$, Doo-Jeong Han, Hack-Youn Kim, \\ Ko-Eun Hwang, Dong-Heon Song, and Cheon-Jei Kim* \\ Department of Food Science and Biotechnology of Animal Resources, Konkuk University, Seoul 143-701, Korea \\ ${ }^{1}$ Research Institute for Meat Science and Culture, Konkuk University, Seoul 143-701, Korea
}

\begin{abstract}
Ground pork containing $0,1,2$, or $3 \%$ rice bran fiber was prepared. $\mathrm{pH}$ increased as the amount of rice bran fiber added increased $(p<0.05)$ but decreased during storage. The lightness and redness values of the raw ground pork decreased with the addition of rice bran fiber, and ground pork containing 3\% rice bran fiber had the highest yellowness value during early storage $(p<0.05)$. Moreover, adding rice bran fiber was not associated with color stability during storage. Samples containing 2 or $3 \%$ rice bran fiber had improved cooking loss, hardness, gumminess, and chewiness. Furthermore, rice bran fiber enhanced tenderness, juiciness, and overall acceptability on a sensory evaluation. These physico-chemical properties were maintained to the final storage period. The best results were obtained with ground pork containing 2 or $3 \%$ rice bran fiber. Rice bran fiber combined with useful antioxidants may be a more effective approach to increase the stability of ground pork during cold storage.
\end{abstract}

Key words: rice bran fiber, dietary fiber, ground pork, chilled storage

\section{Introduction}

Recently, consumers that value the importance of health have been demanding functional and healthy meat products. Functional meat and meat products are respectively manufactured by feeding functional material to livestock or by adding functional source to meat products with the aim of satisfying the needs of these consumers in regards to making low-fat and low-calories meat products (Jimenez Colmenero, 2000; Yang et al., 2002; Youssef and Barbut, 2011). These functional materials, mainly obtained from plants, have positive effects when added to meat and one of these functional materials is dietary fiber. Dietary fibers are derivatives that are not digested by enzymes in the human body and include oligosaccharides, polysaccharides, and lignin (Lim et al., 2004). The positive physiological effects of these materials are already well known, especially in the meat processing industry, the addition of dietary fiber to meat products

\footnotetext{
*Corresponding author: Cheon-Jei Kim, Department of Food science and Biotechnology of Animal Resources, Konkuk University, Seoul 143-701, Korea. Tel: 82-2-450-3684, Fax: 82-2-444-6695, E-mail: kimcj@konkuk.ac.kr
}

improves the binding properties of raw meat, emulsion stability, and mineral holding capacity (Lim et al., 2004; Thebaudin et al., 1997). The dietary fibers used on meat products are typically husk group such as rye bran, oat bran, and wheat bran and vegetable group (García et al., 2002; Yilmaz and Dağlioğlu, 2003; Yilmaz, 2004; Yilmaz, 2005). These previous studies have examined the ability of dietary fibers to improve the quality characteristics of meat products; however, no study has examined the effect of dietary fibers on changing the quality characteristics of ground pork products during storage periods.

One potential source of dietary fiber is rice bran fiber, which is made by rice polishing. In Korea, the amount of rice bran fiber produced annually ranges from 400,000500,000 tons (Choi et al., 2008). This rice bran has a high lipid content which can cause lipid oxidation; however, approximately $20-25 \%$ of this rice bran consists of dietary fibers (Lee and Shin, 2006). Interestingly, pre-processed rice bran (through removal of fat etc.) has been used to improve the quality of various meat products. Previous studies have examined many aspects of rice bran including; 1) the effects of rice bran fiber on the quality characteristics of various meat products (Choi et al., 2008; Huang et al., 2005), 2) the utilization of a fat 
replacer (Choi et al., 2009; Choi et al., 2010). Most of these studies examined the effect of adding 1-3\% rice bran fiber levels. Consumers usually consume commercial meat products after the product has been distributed and stored rather than consuming it directly after manufacturing; therefore, there is a need to examined the effect of dietary fibers on the quality characteristics of meat products during storage.

Therefore, we evaluated changes in the physicochemical and sensorial properties of ground pork containing various concentrations of rice bran fiber. Our results provide important data for consumers and researchers interested in meat products containing dietary fiber, especially for products containing rice bran fiber.

\section{Materials and Methods}

\section{Preparation and processing of rice bran fiber}

The rice bran (Japonica rice cultivar, Oriza sativa L.) was purchased from a market in Geochang, Korea. It was ground in a mill, to pass through a 25 mesh sieve, roasted at $105^{\circ} \mathrm{C}$ and defatted with hexane ( $n$-hexane $95 \%$ ) in a shaker (BS-11, Lab. Companion, Korea) overnight. The defatted rice bran was treated with $0.6 \%$ termamyl (heat stable alpha-amylase) at $95^{\circ} \mathrm{C}$ for $1 \mathrm{~h}$ to remove starch, followed by filtration. The residue was washed three times with four volumes of hot water $\left(100^{\circ} \mathrm{C}\right)$, allowed to equilibrate at room temperature $\left(20^{\circ} \mathrm{C}, 6 \mathrm{~h}\right)$ then washed with $99.9 \%$ ethanol (preheated to $60^{\circ} \mathrm{C}$ ), followed by filtration. The resulting residue was dried $\left(55^{\circ} \mathrm{C}\right)$ overnight using an air oven and cooled. The rice bran fiber was placed in polyethylene bags, vacuum sealed using vacuum packaging system (FJ-500XL, Fujee Tech., Korea), and stored at $4^{\circ} \mathrm{C}$ until used. The chemical and physical properties of rice bran fiber is as follows; moisture (11.73 \pm $0.32 \mathrm{mg} / 100 \mathrm{~g})$, protein $(21.91 \pm 0.43 \mathrm{mg} / 100 \mathrm{~g})$, fat $(4.31$ $\pm 0.43 \mathrm{mg} / 100 \mathrm{~g})$, ash $(7.42 \pm 0.24 \mathrm{mg} / 100 \mathrm{~g})$, digestible carbohydrates $(1.38 \pm 0.18 \mathrm{mg} / 100 \mathrm{~g})$, dietary fiber $(53.25$ $\pm 0.79 \mathrm{mg} / 100 \mathrm{~g}), \mathrm{pH}(7.07 \pm 0.04)$, and color parameters (CIE L ${ }^{*}, 66.10 \pm 0.20$; CIE a ${ }^{*}, 4.73 \pm 0.04$; CIE b ${ }^{*}, 16.06 \pm$ 0.06) (Choi et al., 2011).

\section{Manufacturing of ground pork}

Fresh pork meats were purchased from a local processor at $48 \mathrm{~h}$ postmortem. Pork back fat was also collected. All subcutaneous and inter-muscular fat and visible connective tissue were removed from the fresh ham muscles. Lean muscles and pork back fat were initially ground through $\varnothing-8 \mathrm{~mm}$ plate using a meat grinder (PM-70,
Mainca, Spain). The ground meat and fat were packaged with Nylon/PE film bags, and stored at $4^{\circ} \mathrm{C}$.

All samples were composed by $80 \%$ pork ham ( $M$. biceps femoris, M. semitendinosus, and M. semimembranosus), $15 \%$ pork fat, $5 \%$ ice water and $1.5 \% \mathrm{NaCl}$. The mixtures from each batch were mixed by hand for $5 \mathrm{~min}$. Each batch of samples consisted of four samples, which differed in composition with respect to rice bran fiber levels $(0,1,2$, and $3 \%)$. Mixed samples were packaged with Nylon/PE film bags, stored in a refrigerator $\left(4^{\circ} \mathrm{C}\right)$ for 15 $\mathrm{d}$ and evaluated after $0,3,6,9,12$, and $15 \mathrm{~d}$ of storage periods.

\section{pH measurements}

The $\mathrm{pH}$ values of samples were determined with a $\mathrm{pH}$ meter (Model 340, Mettler-Toledo GmbH, Switzerland). The $\mathrm{pH}$ values of samples were measured by blending a 5 g sample with $20 \mathrm{~mL}$ distilled water for $60 \mathrm{~s}$ in a homogenizer at 8,000 rpm (Ultra-Turrax SK15, Janke \& Kunkel, Germany).

\section{Instrumental color evaluations}

The instrumental color analysis of ground pork was conducted. Color measurements were taken with colorimeter (Chroma meter CR-210, Minolta, Japan; illuminate C, calibrated with white standard plate CIE $L^{*}=97.83$, CIE $a^{*}=-0.43$, CIE $b^{*}=+1.98$ ), consisted of an $8 \mathrm{~mm}$ diameter measuring area and a $50 \mathrm{~mm}$ diameter illumination area. Color values (CIE L ${ }^{*}, a^{*}$, and $\left.b^{*}\right)$ were measured on the surface of samples and results were taken in triplicate for each sample.

\section{Cooking loss}

Cooking loss was determined by calculating the weight differences before and after cooking as follows. All samples evaluated after at $0,3,6,9,12$, and $15 \mathrm{~d}$ of storage.

Cooking loss (\%)

$=[($ weight of raw sample $(\mathrm{g})-$ weight of cooked sample (g))/weight of raw sample $(\mathrm{g})] \times 100$

\section{TBA (2-thiobarbituric acid) values}

Lipid oxidation was assessed in triplicate by the TBA (2-thiobarbituric acid) method of Tarladgis et al. (1960) with minor modifications. A $10 \mathrm{~g}$ sample was blended with $50 \mathrm{~mL}$ distilled water for $2 \mathrm{~min}$ and then transferred to a distillation tube. The cup used for blending was washed with an additional $47.5 \mathrm{~mL}$ of distilled water, which was added to the same distillation flask with 2.5 
$\mathrm{mL} 4 \mathrm{~N} \mathrm{HCl}$ and a few drops of an antifoam agent, silicone o/w (KMK-73, Shin-Etsu Silicone Co., Ltd., Korea). The mixture was distilled and $50 \mathrm{~mL}$ distillate was collected. $5 \mathrm{~mL}$ of $0.02 \mathrm{M} 2$-thiobarbituric acid in $90 \%$ acetic acid (TBA reagent) was added to a vial containing 5 $\mathrm{mL}$ of the distillate and mixed well. The vials were capped and heated in a boiling water bath for $30 \mathrm{~min}$ to develop the chromogen and cooled to room temperature. The OD was measured at $538 \mathrm{~nm}$, against a blank prepared with $5 \mathrm{~mL}$ distilled water and $5 \mathrm{~mL}$ TBA-reagent, using a UV/VIS spectrophotometer (Optizen 2120 UV plus, Mecasys Co., Ltd., Korea). Thiobarbituric acid-reactive substances (TBARS) were calculated from a standard curve (8-50 nmol) of malondialdehyde (MDA), freshly prepared by acidification of TEP (1,1,3,3-tetraethoxy propane). Reagents were obtained from Sigma (UK). The TBA levels were calculated as $\mathrm{mg} \mathrm{MDA} / \mathrm{kg}$ meat.

\section{VBN (volatile basic nitrogen) values}

VBN $(\mathrm{mg} \%)$ test was performed to determine the extent of protein deterioration during refrigerated storage $\left(4^{\circ} \mathrm{C}\right)$. VBN was measured by the modified micro diffusion assay according to the method of Pearson (1968).

$$
\begin{aligned}
& \operatorname{VBN}(\mathrm{mg} \%) \\
& =[(a-b) \times(f \times 0.02 \times N \times 14.007 \times 100 \times 100) / S]
\end{aligned}
$$

Where, $a=$ titer for sample, $b=$ titer for blank, $f=$ factor of reagent, $N=$ normality, $S=$ sample weight $(\mathrm{g})$

\section{Texture profile analysis (TPA)}

The profile analysis was performed in duplicate on each ground pork. Samples were cooked at $75^{\circ} \mathrm{C}$ for 30 min, and then cooked samples were cooled to at room temperature for $1 \mathrm{~h}$ to determine texture properties. The textural properties of each sample were measured by a spherical probe (5 diameters), set attached to a Texture Analyzer (TA-XT2 $i$, Stable Micro System Ltd., UK). The test conditions were as follow : stroke, $20 \mathrm{~g}$; test speed, $2.0 \mathrm{~mm} / \mathrm{s}$; distance, $10.0 \mathrm{~mm}$. Data were collected and analyzed from the hardness $(\mathrm{kg})$, springiness, cohesiveness, gumminess $(\mathrm{kg})$, and chewiness $(\mathrm{kg})$ values.

\section{Sensory evaluations}

The samples were evaluated for color, flavor, juiciness, tenderness, and overall acceptability, and sensory evaluation were performed in triplicate for each sample using trained panelists. The panel consisted of 15 members from the Department of Food Sciences and Biotechnology of Animal Resources at Konkuk University in Korea.
15 panelists were chosen from 20 potential panelists using basic taste identification test. The cooked samples as previously described were cooled to room temperature at $25 \pm 1^{\circ} \mathrm{C}$ and cut and served to the panelists in random order. The sensory evaluations were performed by the panelists under fluorescence lighting. Panelists were instructed to cleanse their palates between samples using water. The color, flavor, and overall acceptability ( $1=$ extremely undesirable, $10=$ extremely desirable), tenderness ( $1=$ extremely tough, $10=$ extremely tender), juiciness ( $1=$ extremely dry, $10=$ extremely juicy) of the cooked samples were evaluated using a 10-point descriptive scale.

\section{Statistical analysis}

An analysis of variance were performed on all the variables measured using the General Linear Model (GLM) procedure of the SAS statistical package (SAS Institute, Inc., 1999). Duncan's multiple range test $(p<0.05)$ was used to determine differences between treatment means.

\section{Results and Discussion}

\section{Changes in $\mathrm{pH}$ value and instrumental color of raw ground pork}

Fig. 1 shows the changes in the $\mathrm{pH}$ value of ground pork containing rice bran fiber during refrigerated storage $(0,3,6,9,12$, and $15 \mathrm{~d})$. In these experiments, the $\mathrm{pH}$ values of raw pork meat and rice bran fiber were 5.87 and 7.07 , respectively. As the rice bran fiber level was increased so did the $\mathrm{pH}$ value during the initial storage period,

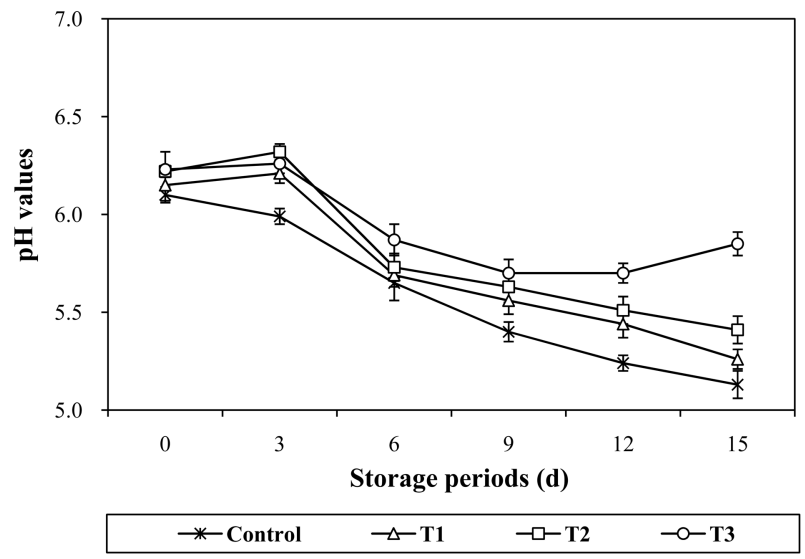

Fig. 1. Change in $\mathrm{pH}$ values of ground pork with containing various rice bran fiber levels during chilled storage periods. Control, without rice bran fiber; T1, ground pork added with $1 \%$ rice bran fiber; $\mathrm{T} 2$, ground pork added with $2 \%$ rice bran fiber; $\mathrm{T} 3$, ground pork added with $3 \%$ rice bran fiber 
Table 1. Effect of rice bran fiber levels on changes in instrumental color of external uncooked ground pork during storage periods

\begin{tabular}{|c|c|c|c|c|c|}
\hline \multirow{2}{*}{ Traits } & \multirow{2}{*}{$\begin{array}{c}\text { Storage } \\
\text { periods }(d)\end{array}$} & \multirow{2}{*}{ Control } & \multicolumn{3}{|c|}{ Treatments $^{1)}$} \\
\hline & & & $\mathrm{T} 1$ & $\mathrm{~T} 2$ & T3 \\
\hline \multirow{6}{*}{$\mathrm{CIE} \mathrm{L}^{*}$} & 0 & $51.97 \pm 0.59^{\mathrm{Ae}}$ & $51.41 \pm 0.29^{\mathrm{Bc}}$ & $50.38 \pm 0.57^{\mathrm{Cd}}$ & $49.72 \pm 0.48^{\mathrm{De}}$ \\
\hline & 3 & $53.06 \pm 0.55^{\mathrm{Ad}}$ & $51.91 \pm 0.36^{\mathrm{Bc}}$ & $50.49 \pm 0.59^{\mathrm{Cd}}$ & $50.58 \pm 0.22^{\mathrm{Cd}}$ \\
\hline & 6 & $55.50 \pm 0.86^{\mathrm{Ac}}$ & $55.04 \pm 1.46^{\mathrm{Ab}}$ & $52.31 \pm 1.45^{\mathrm{Bc}}$ & $51.79 \pm 0.95^{\mathrm{Bc}}$ \\
\hline & 9 & $55.08 \pm 1.08^{\mathrm{Ac}}$ & $55.44 \pm 1.49^{\mathrm{Ab}}$ & $53.49 \pm 1.40^{\mathrm{Bb}}$ & $53.88 \pm 1.43^{\mathrm{Bb}}$ \\
\hline & 12 & $57.67 \pm 1.25^{\mathrm{Ab}}$ & $56.83 \pm 1.50^{\mathrm{Ba}}$ & $55.52 \pm 1.15^{\mathrm{Cb}}$ & $54.75 \pm 1.20^{\mathrm{Ca}}$ \\
\hline & 15 & $56.79 \pm 1.85^{\mathrm{Aa}}$ & $56.82 \pm 1.45^{\mathrm{Aa}}$ & $54.29 \pm 1.35^{\mathrm{Ba}}$ & $53.76 \pm 1.66^{\mathrm{Bb}}$ \\
\hline \multirow{6}{*}{ CIE a* } & 0 & $15.81 \pm 0.47^{\mathrm{Aa}}$ & $15.29 \pm 0.71^{\mathrm{Aa}}$ & $13.01 \pm 0.36^{\mathrm{Ba}}$ & $11.97 \pm 0.43^{\mathrm{Ca}}$ \\
\hline & 3 & $14.44 \pm 0.55^{\mathrm{Ab}}$ & $12.33 \pm 0.45^{\mathrm{Bb}}$ & $11.63 \pm 0.42^{\mathrm{BCb}}$ & $10.86 \pm 0.66^{\mathrm{Cb}}$ \\
\hline & 6 & $13.91 \pm 0.40^{\mathrm{Abc}}$ & $11.79 \pm 0.47^{\mathrm{Bbc}}$ & $11.71 \pm 0.46^{\mathrm{Bb}}$ & $9.81 \pm 0.50^{\mathrm{Cc}}$ \\
\hline & 9 & $13.78 \pm 0.30^{\mathrm{Abc}}$ & $11.82 \pm 0.26^{\mathrm{Bbc}}$ & $11.53 \pm 0.37^{\mathrm{Bb}}$ & $9.83 \pm 0.80^{\mathrm{Cc}}$ \\
\hline & 12 & $13.43 \pm 0.36^{\mathrm{Ac}}$ & $11.33 \pm 0.28^{\mathrm{Bc}}$ & $11.18 \pm 0.46^{\mathrm{Bb}}$ & $10.09 \pm 0.27^{\mathrm{Cbc}}$ \\
\hline & 15 & $13.25 \pm 0.35^{\mathrm{Ac}}$ & $11.35 \pm 0.50^{\mathrm{Bc}}$ & $11.15 \pm 0.24^{\mathrm{Bb}}$ & $9.86 \pm 0.34^{\mathrm{Cc}}$ \\
\hline \multirow{6}{*}{$\mathrm{CIE} \mathrm{b}^{*}$} & 0 & $9.40 \pm 0.20^{\mathrm{Cc}}$ & $10.27 \pm 0.16^{\mathrm{Bc}}$ & $10.19 \pm 0.32^{\mathrm{Bc}}$ & $11.26 \pm 0.30^{\mathrm{Ad}}$ \\
\hline & 3 & $10.25 \pm 0.14^{\mathrm{Dab}}$ & $10.93 \pm 0.38^{\mathrm{Bb}}$ & $10.72 \pm 0.27^{\mathrm{Cb}}$ & $11.50 \pm 0.10^{\mathrm{Acd}}$ \\
\hline & 6 & $10.16 \pm 0.88^{\mathrm{Cb}}$ & $10.99 \pm 0.74^{\mathrm{Bab}}$ & $11.33 \pm 0.60^{\mathrm{ABa}}$ & $11.69 \pm 0.50^{\mathrm{Ac}}$ \\
\hline & 9 & $10.52 \pm 1.08^{\mathrm{Bab}}$ & $11.44 \pm 0.75^{\text {Aab }}$ & $11.46 \pm 0.84^{\mathrm{Aa}}$ & $11.58 \pm 0.63^{\mathrm{Acd}}$ \\
\hline & 12 & $10.76 \pm 0.85^{\mathrm{Ca}}$ & $11.51 \pm 0.69^{\mathrm{Bab}}$ & $11.50 \pm 0.76^{\mathrm{Ba}}$ & $12.11 \pm 0.68^{\mathrm{Ab}}$ \\
\hline & 15 & $10.83 \pm 0.63^{\mathrm{Ca}}$ & $11.57 \pm 0.30^{\mathrm{Ba}}$ & $11.51 \pm 0.38^{\mathrm{Ba}}$ & $12.77 \pm 0.71^{\mathrm{Aa}}$ \\
\hline
\end{tabular}

All values are mean \pm SD.

${ }^{\text {A-D }}$ Means in the same row with different letters are significantly different $(p<0.05)$.

${ }^{\mathrm{a}-\mathrm{e}}$ Means in the same column with different letters are significantly different $(p<0.05)$.

${ }^{1)}$ Treatments: T1, ground pork added with $1 \%$ rice bran fiber; T2, ground pork added with $2 \%$ rice bran fiber; T3, ground pork added with $3 \%$ rice bran fiber

where $\mathrm{T} 3$ (3\% rice bran fiber) has the highest $\mathrm{pH}$ value $(p<0.05)$. Choi et al. (2008) reported similar results and demonstrated that occurred because the $\mathrm{pH}$ of rice bran fiber is high. The $\mathrm{pH}$ values of the control and all treatments significantly decreased during storage and all samples had the lowest $\mathrm{pH}$ values at $15 \mathrm{~d}(p<0.05)$. The high $\mathrm{pH}$ value of the ground pork containing the rice bran fiber at the early storage period contributed to the formation and maintenance of the $\mathrm{pH}$, which was high on the final storage day. Vaithiyanathan et al. (2011) obtained similar results in regards to the $\mathrm{pH}$ value. Demeyer and Vanderkerckhove (1979) suggested that the change in the $\mathrm{pH}$ values of the meat products in refrigerated storage was affected by the addition of raw materials or additives and the formulations or storage conditions could be adjusted to control the $\mathrm{pH}$. Also, the reason for the decline of the $\mathrm{pH}$ values during storage was because of the accumulation of lactic acid from proliferating microorganisms (Pearson and Young, 1989). Finally, various factors can effect changes in the $\mathrm{pH}$ values during storage periods; however, we found that property of rice bran fiber has the largest influence on $\mathrm{pH}$ value during storage periods.

Meat color is the one of most important factors that influences the quality properties of meat products and is affected by a chemical change in myoglobin (Ang and Huang, 1994). Especially, for meat products, additives greatly influence the color formation and stability of the final product. Table 2 shows the changes in the external color of ground pork containing rice bran fiber. The lightness $\left(\mathrm{CIE} \mathrm{L}^{*}\right)$ of the ground pork decreased at increased rice bran fiber levels during the initial storage periods $(p<0.05)$. A similar trend was also observed at the end of the storage periods. Choi et al. (2008) and Huang et al. (2005) reported similar results. As the storage periods increased, the lightness of all sample decreased significantly $(p<0.05)$. Hutchings (1999) reported that the lightness depended on moisture content, thus this phenomenon may be relative to the loss of moisture in ground pork. Values for redness (CIE $\left.a^{*}\right)$ and yellowness (CIE $\left.b^{*}\right)$ were also different at the different rice bran fiber levels $(p<$ $0.05)$. The redness values were lower $(p<0.05)$ in the rice bran fiber treatment groups than the control and the yellowness increased significantly $(p<0.05)$ with an increase in the rice bran fiber content during the initial storage periods. At longer storage periods, the redness of all samples decreased significantly $(p<0.05)$, where T3 showed 
Table 2. Change in textural properties of cooked ground pork with various rice bran fiber levels during chilled storage periods

\begin{tabular}{|c|c|c|c|c|c|}
\hline \multirow{2}{*}{ Traits } & \multirow{2}{*}{$\begin{array}{c}\text { Storage } \\
\text { periods }(\mathrm{d})\end{array}$} & \multirow{2}{*}{ Control } & \multicolumn{3}{|c|}{ Treatments $^{1)}$} \\
\hline & & & $\mathrm{T} 1$ & $\mathrm{~T} 2$ & $\mathrm{~T} 3$ \\
\hline \multirow{6}{*}{ Hardness (kg) } & 0 & $0.66 \pm 0.04^{\mathrm{Cd}}$ & $0.76 \pm 0.10^{\mathrm{BCcd}}$ & $0.86 \pm 0.09^{\mathrm{ABb}}$ & $0.96 \pm 0.20^{\mathrm{Abcd}}$ \\
\hline & 3 & $0.69 \pm 0.06^{\mathrm{Bcd}}$ & $0.70 \pm 0.06^{\mathrm{Bd}}$ & $0.85 \pm 0.06^{\mathrm{Ab}}$ & $0.84 \pm 0.06^{\mathrm{Ad}}$ \\
\hline & 6 & $0.75 \pm 0.09^{\mathrm{Cbc}}$ & $0.84 \pm 0.10^{\mathrm{Bbc}}$ & $0.98 \pm 0.11^{\mathrm{Aa}}$ & $0.86 \pm 0.08^{\mathrm{Bcd}}$ \\
\hline & 9 & $0.80 \pm 0.08^{\mathrm{Bab}}$ & $0.83 \pm 0.09^{\mathrm{Bbc}}$ & $0.96 \pm 0.09^{\mathrm{Aa}}$ & $1.01 \pm 0.19^{\mathrm{Aab}}$ \\
\hline & 12 & $0.87 \pm 0.07^{\mathrm{Ca}}$ & $0.89 \pm 0.08^{\mathrm{BCb}}$ & $0.95 \pm 0.10^{\mathrm{ABa}}$ & $0.98 \pm 0.09^{\mathrm{Abc}}$ \\
\hline & 15 & $0.83 \pm 0.10^{\mathrm{Ca}}$ & $0.97 \pm 0.11^{\mathrm{Ba}}$ & $0.99 \pm 0.14^{\mathrm{Ba}}$ & $1.13 \pm 0.13^{\mathrm{Aa}}$ \\
\hline \multirow{6}{*}{ Springiness } & 0 & $0.89 \pm 0.02^{\mathrm{Ba}}$ & $0.92 \pm 0.02^{\mathrm{ABa}}$ & $0.95 \pm 0.03^{\mathrm{Aa}}$ & $0.96 \pm 0.04^{\mathrm{Aa}}$ \\
\hline & 3 & $0.86 \pm 0.03^{\mathrm{ab}}$ & $0.87 \pm 0.02^{\mathrm{ab}}$ & $0.88 \pm 0.02^{\mathrm{b}}$ & $0.87 \pm 0.02^{\mathrm{b}}$ \\
\hline & 6 & $0.87 \pm 0.02^{\mathrm{a}}$ & $0.87 \pm 0.03^{\mathrm{ab}}$ & $0.88 \pm 0.04^{\text {bc }}$ & $0.89 \pm 0.05^{\mathrm{b}}$ \\
\hline & 9 & $0.85 \pm 0.03^{\mathrm{ab}}$ & $0.86 \pm 0.03^{b}$ & $0.88 \pm 0.03^{b}$ & $0.88 \pm 0.02^{\mathrm{b}}$ \\
\hline & 12 & $0.82 \pm 0.02^{\mathrm{b}}$ & $0.84 \pm 0.03^{\mathrm{b}}$ & $0.85 \pm 0.04^{\text {bc }}$ & $0.84 \pm 0.04^{\text {bc }}$ \\
\hline & 15 & $0.82 \pm 0.04^{\mathrm{b}}$ & $0.83 \pm 0.03^{\mathrm{b}}$ & $0.82 \pm 0.03^{\mathrm{c}}$ & $0.81 \pm 0.03^{c}$ \\
\hline \multirow{6}{*}{ Cohesiveness } & 0 & $0.47 \pm 0.07$ & $0.49 \pm 0.06$ & $0.48 \pm 0.04$ & $0.45 \pm 0.04$ \\
\hline & 3 & $0.44 \pm 0.03^{\mathrm{AB}}$ & $0.45 \pm 0.04^{\mathrm{A}}$ & $0.45 \pm 0.02^{\mathrm{AB}}$ & $0.42 \pm 0.03^{\mathrm{B}}$ \\
\hline & 6 & $0.48 \pm 0.02$ & $0.47 \pm 0.03$ & $0.47 \pm 0.04$ & $0.49 \pm 0.04$ \\
\hline & 9 & $0.47 \pm 0.04$ & $0.48 \pm 0.02$ & $0.48 \pm 0.02$ & $0.47 \pm 0.04$ \\
\hline & 12 & $0.48 \pm 0.07$ & $0.49 \pm 0.06$ & $0.46 \pm 0.06$ & $0.47 \pm 0.05$ \\
\hline & 15 & $0.45 \pm 0.06$ & $0.49 \pm 0.03$ & $0.46 \pm 0.04$ & $0.47 \pm 0.03$ \\
\hline \multirow{6}{*}{ Gumminess (kg) } & 0 & $0.31 \pm 0.05^{\mathrm{Bc}}$ & $0.38 \pm 0.09^{\mathrm{ABbc}}$ & $0.42 \pm 0.07^{\mathrm{Aab}}$ & $0.42 \pm 0.11^{\mathrm{Abc}}$ \\
\hline & 3 & $0.31 \pm 0.04^{\mathrm{Bc}}$ & $0.32 \pm 0.05^{\mathrm{Bd}}$ & $0.38 \pm 0.03^{\mathrm{Ab}}$ & $0.36 \pm 0.04^{\mathrm{Ac}}$ \\
\hline & 6 & $0.35 \pm 0.03^{\mathrm{Cbc}}$ & $0.39 \pm 0.05^{\mathrm{BCbc}}$ & $0.46 \pm 0.04^{\mathrm{Aa}}$ & $0.42 \pm 0.05^{\mathrm{Bbc}}$ \\
\hline & 9 & $0.38 \pm 0.05^{\text {Bab }}$ & $0.37 \pm 0.05^{\mathrm{Bcd}}$ & $0.47 \pm 0.04^{\mathrm{Aa}}$ & $0.49 \pm 0.11^{\mathrm{Aab}}$ \\
\hline & 12 & $0.41 \pm 0.08^{\mathrm{a}}$ & $0.43 \pm 0.05^{\mathrm{ab}}$ & $0.42 \pm 0.06^{\mathrm{ab}}$ & $0.46 \pm 0.05^{\mathrm{b}}$ \\
\hline & 15 & $0.37 \pm 0.07^{\mathrm{Cab}}$ & $0.47 \pm 0.08^{\mathrm{ABa}}$ & $0.45 \pm 0.06^{\mathrm{Ba}}$ & $0.53 \pm 0.07^{\mathrm{Aa}}$ \\
\hline \multirow{6}{*}{ Chewiness (kg) } & 0 & $0.31 \pm 0.05^{\mathrm{Bb}}$ & $0.37 \pm 0.09^{\mathrm{ABab}}$ & $0.41 \pm 0.07^{\text {Aabc }}$ & $0.41 \pm 0.11^{\text {Aab }}$ \\
\hline & 3 & $0.31 \pm 0.04^{\mathrm{Bb}}$ & $0.32 \pm 0.05^{\mathrm{Bc}}$ & $0.38 \pm 0.03^{\mathrm{Ac}}$ & $0.35 \pm 0.04^{\mathrm{Ab}}$ \\
\hline & 6 & $0.34 \pm 0.03^{\mathrm{Cab}}$ & $0.38 \pm 0.05^{\mathrm{BCab}}$ & $0.43 \pm 0.04^{\mathrm{Aab}}$ & $0.41 \pm 0.05^{\mathrm{ABab}}$ \\
\hline & 9 & $0.36 \pm 0.06^{\mathrm{Bab}}$ & $0.36 \pm 0.05^{\mathrm{Bbc}}$ & $0.45 \pm 0.04^{\mathrm{Aa}}$ & $0.46 \pm 0.11^{\mathrm{Aa}}$ \\
\hline & 12 & $0.38 \pm 0.06^{\mathrm{a}}$ & $0.41 \pm 0.05^{\mathrm{ab}}$ & $0.39 \pm 0.06^{\mathrm{bc}}$ & $0.43 \pm 0.06^{\mathrm{a}}$ \\
\hline & 15 & $0.36 \pm 0.07^{\mathrm{Cab}}$ & $0.42 \pm 0.05^{\mathrm{ABa}}$ & $0.40 \pm 0.05^{\mathrm{BCabc}}$ & $0.46 \pm 0.04^{\mathrm{Aa}}$ \\
\hline
\end{tabular}

All values are mean $\pm \mathrm{SD}$.

${ }^{\mathrm{A}-\mathrm{C}}$ Means in the same row with different letters are significantly different $(p<0.05)$.

${ }^{\mathrm{a}-\mathrm{d}}$ Means in the same column with different letters are significantly different $(p<0.05)$.

${ }^{1)}$ Treatments: T1, ground pork added with $1 \%$ rice bran fiber; T2, ground pork added with $2 \%$ rice bran fiber; T3, ground pork added with $3 \%$ rice bran fiber

the lowest redness at the end of the storage periods. Phillips et al. (2001) suggested that the decrease in redness during storage was closely related to lipid oxidation; therefore the lower redness of T3 (the higher TBA value) may have been due to increased lipid oxidation. The yellowness of all sample increased significantly $(p<0.05)$ as the storage time increased. This increase in yellowness with storage period was also observed in the control, which had the lowest yellowness at $0 \mathrm{~d}(p<0.05)$. The addition of rice bran fiber initially affected the color parameters of ground pork; however, a similar change in color during storage was observed for all samples and the addition of rice bran fiber was not strongly correlated with color stability.

\section{Change in cooking loss of ground pork}

Improvements in cooking loss are a main reason to add dietary fiber to meat products. Many researchers have reported an increase in cooking loss regardless of dietary fiber source (Aleson-Carbonell et al., 2005; Huang et al., 2005; Yilmaz, 2005). Fig. 2 shows the effect of the rice bran fiber on the average cooking loss of ground pork. The control showed the highest cooking loss $(p<0.05)$ and no significantly differences were observed between $\mathrm{T} 2$ and T3 at $0 \mathrm{~d}(p>0.05)$. The cooking loss steadily increased as a function of storage time; however, storage 


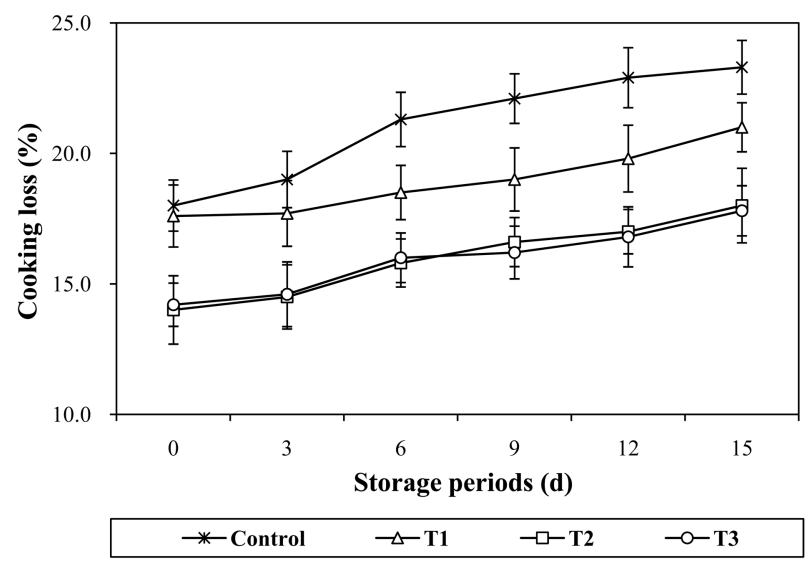

Fig. 2. Change in cooking loss of ground pork with containing various rice bran fiber levels during chilled storage periods. Control, without rice bran fiber; T1, ground pork added with $1 \%$ rice bran fiber; $\mathrm{T} 2$, ground pork added with $2 \%$ rice bran fiber; T3, ground pork added with $3 \%$ rice bran fiber

time did not affect the differences of cooking loss between the early control and treatments. Moreover, there were no significantly difference $(p>0.05)$ in the purge loss among all samples (data not shown). T2 and T3 had the lowest cooking loss after the final storage time, and control had an inferior cooking loss as contrasted with rice bran fiber treatment. Generally, cooking loss improves when the $\mathrm{pH}$ is higher than the isoelectric point $(\mathrm{pH}$ value 5.0). Also during storage periods, cooking loss is affected by many other factors such as denaturation and deterioration of protein (Flores et al., 2000; Kauffman et al., 1986). The lower cooking loss observed during the initial storage periods in samples containing the rice bran fiber at initial storage periods was most likely due to the water holding capacity and the higher $\mathrm{pH}$ values of rice bran fiber. Eventually, the addition of rice bran fiber to ground pork prevented the loss of moisture during storage periods as well as after immediately manufacturing against the physical change such as cooking.

\section{Changes in TBA and VBN values of raw ground pork}

The TBA value is a good indicator of lipid oxidation and rancidity (Jones and Rogers, 1971), and the TBA values of the raw ground pork containing rice bran fiber are shown in Fig. 3. There was a significant increase $(p<$ 0.05 ) in TBA values of all samples after a $15 \mathrm{~d}$ storage period. In the storage final stage, $\mathrm{T} 3$ had the highest TBA value compared to the other samples; however, this difference was not significant ( $p>0.05$ ). Suh (1984) reported that meat products with a TBA value of more than $1 \mathrm{mg} /$

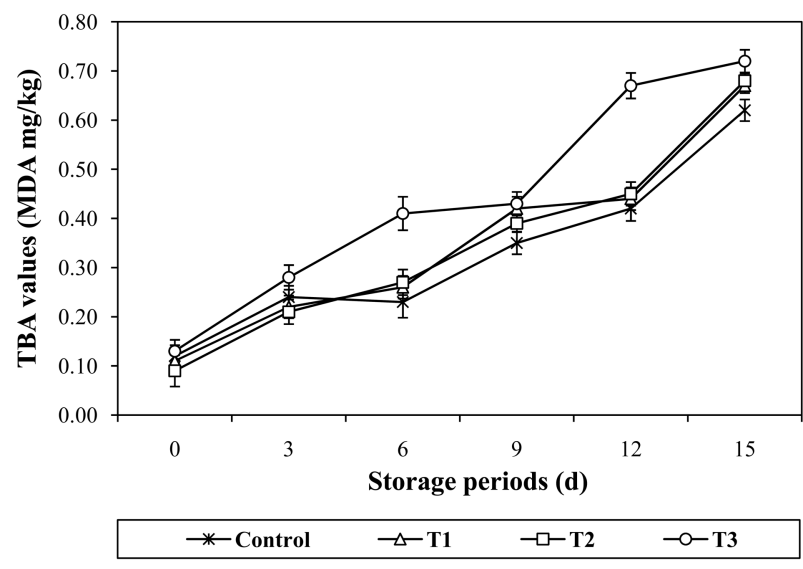

Fig. 3. Change in TBA (2-thiobarbituric acid) values of ground pork with containing various rice bran fiber levels during chilled storage periods. Control, without rice bran fiber; $\mathrm{T} 1$, ground pork added with $1 \%$ rice bran fiber; $\mathrm{T} 2$, ground pork added with $2 \%$ rice bran fiber; $\mathrm{T} 3$, ground pork added with $3 \%$ rice bran fiber

kg TBA cannot be consumed because of lipid rancidity. Turner et al. (1954) also reported that about a TBA value of $1.2 \mathrm{mg} / \mathrm{kg}$ TBA indicates that lipid oxidation was already progressed significantly. The TBA values of all samples at end of storage ranged from 0.62-0.72 MDA $\mathrm{mg} / \mathrm{kg}$, all of which were below the threshold for consumption. Park et al. (2003) reported that rice bran contains phytonutrients such as vitamin $\mathrm{B}$, vitamin $\mathrm{E}$, octacosanol, and $\gamma$-oryzanol. In addition, Woo et al. (2005) indicated that tocotrienol extracted from rice bran produced a high antioxidative effect. However, in this study, the addition of rice bran fiber was not related to the TBA values. Although the rice bran was passed through defatted process, the rice bran fiber still contains about $4 \%$ fat. Also, the defatted process uses organic solvents ( $n$-hexane), which can remove antioxidants in the rice bran. Thus, the rice bran fiber did not inhibit lipid oxidation.

The VBN value is a good indicator of protein deterioration and decomposition. Proteins in meat are decomposed into peptides and amino acids by enzymes and microorganisms when stored under cold conditions (Field and Chang, 1969). The VBN values of the control and all treatments increased as a function of the storage periods (Fig. 4) and at end of storage, the control had higher VBN values than the treatment groups $(p>0.05)$. Kim et al. (2008) previously reported a high VBN value for samples treated with hot-air dried tomato powder. Kang et al. (2002) indicated that the increase of VBN value is associated with the growth of bacteria and protein deterioration. However, there is still no valid research on correlation 


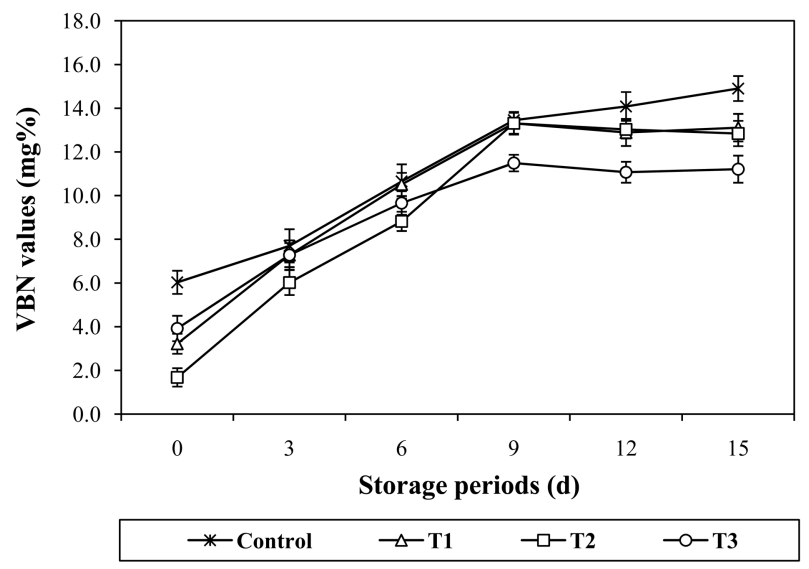

Fig. 4. Change in VBN (volatile basic nitrogen) values of ground pork with containing various rice bran fiber levels during chilled storage periods. Control, without rice bran fiber; $\mathrm{T} 1$, ground pork added with $1 \%$ rice bran fiber; T2, ground pork added with $2 \%$ rice bran fiber; T3, ground pork added with $3 \%$ rice bran fiber

between the addition of dietary fiber and VBN value, so characteristic of dietary fiber depending on the source is influence factors largest in a change of VBN value. Davies and Board (1998) suggested that a VBN value of $20 \mathrm{mg} \%$ can be used as a threshold to evaluate the degree of freshness of raw and packed meat. All samples in this study fell within this range after storage for $15 \mathrm{~d}$.

\section{Changes in textural properties of ground pork}

Texture is an important factor dictating the quality characteristics of products (Herrero et al., 2007). Table 2 shows the textural properties of cooked ground pork containing various rice bran fiber levels. In the initial texture profile analysis data, the hardness of the samples increased with an increase in the rice bran fiber concentration. A similar trend was observed for the springiness, chewiness, and gumminess. However, there were no significantly difference in cohesiveness among the samples $(p>0.05)$. Choi et al. (2008) previously reported that adding a suitable amount of rice bran fiber improved the textural properties of ground pork meat products. During chilled storage of the samples, a significant increase in the hardness of all samples was observed over the $15 \mathrm{~d}$ storage period $(p<0.05)$. Similar results were observed for the gumminess and chewiness. The springiness decreased after $15 \mathrm{~d}$ relative to the initial springiness $(p<0.05)$. The storage period did not significantly alter the cohesiveness $(p>0.05)$. Towards the end of the storage period (15d), no significant difference in springiness and cohesiveness was observed between the control and treatments $(p>0.05)$ and the difference of hardness between the control and treatment was similar to the $0 \mathrm{~d}$ hardness value. Candogan and Kolsarici (2003) suggested that the hardness increased during refrigerated storage due to water loss. In addition Andrés et al. (2006) reported that the gumminess and chewiness increased with increasing of the hardness during storage, and cohesiveness and springiness did not change significantly. Generally, the increase in hardness during cold storage results from the change in moisture content, if there was no change in these parameters, protein oxidation and modification of polysaccharides can lead to an increase in the hardness of meat products (Ganhão et al., 2010). These previous reports support the results of the textural profile analysis in this study; major reasons of change to textural properties on ground pork with rice bran fiber are presumed to migrate and loss of water. Thus, the addition of rice bran fiber into the meat products not only improves the textural properties during the initial storage period, but also maintains the superior characteristics of the meat during cold storage.

\section{Changes in sensory properties of ground pork}

The sensorial properties of ground pork containing rice bran fiber are shown in Table 3. During the initial storage period, the addition of rice bran fiber did not significantly affect the color and flavor $(p>0.05)$. However, there were significant differences in tenderness and juiciness $(p<0.05)$, these results lead to satisfaction on overall acceptability in T2 and T3. Choi et al. (2008) obtained similar results. As the storage period increase, all sensory scores significantly decreased $(p<0.05)$. However, T2 and T3 were found to have higher sensory scores compare with the control and $\mathrm{T} 1 \mathrm{after}$ storage for $15 \mathrm{~d}$. The tenderness and juiciness had the highest correlation with the addition of rice bran. As described above, T2 and T3 had an excellent cooking loss due to the high water holding capacity of the rice bran fiber. In many studies, the effect of dietary fiber on to taste and flavor were shown to depend on the properties of the dietary fiber, and the addition of the appropriate dietary fiber was shown to positively affect the tenderness, juiciness and sensory evaluation during the early and final storage periods (Aleson-Carbonell et al., 2005; Choi et al., 2008; Huang et al., 2005).

The addition of rice bran fiber into ground pork greatly affected the color, cooking loss, textural and sensorial properties during the early storage periods. For these characteristics, all treatment changes were similar to the control during the storage periods, where the samples with containing 2 and 3\% rice bran fiber had the best cooking loss and textural and sensorial properties after 
Table 3. Change in sensorial evaluation of cooked ground pork with various rice bran fiber levels during chilled storage periods

\begin{tabular}{|c|c|c|c|c|c|}
\hline \multirow{2}{*}{ Traits } & \multirow{2}{*}{$\begin{array}{c}\text { Storage } \\
\text { periods (d) }\end{array}$} & \multirow{2}{*}{ Control } & \multicolumn{3}{|c|}{ Treatments $^{1)}$} \\
\hline & & & $\mathrm{T} 1$ & $\mathrm{~T} 2$ & $\mathrm{~T} 3$ \\
\hline \multirow{6}{*}{ Color } & 0 & $7.71 \pm 0.39^{\mathrm{a}}$ & $7.71 \pm 0.76$ & $8.57 \pm 0.53^{\mathrm{a}}$ & $7.86 \pm 1.07$ \\
\hline & 3 & $7.51 \pm 0.53^{\mathrm{a}}$ & $7.57 \pm 0.79$ & $8.00 \pm 0.58^{\mathrm{ab}}$ & $7.82 \pm 0.90$ \\
\hline & 6 & $7.42 \pm 0.62^{\mathrm{Ba}}$ & $7.86 \pm 0.38^{\mathrm{AB}}$ & $8.43 \pm 0.53^{\mathrm{Aa}}$ & $7.71 \pm 0.76^{\mathrm{B}}$ \\
\hline & 9 & $7.29 \pm 0.49^{\mathrm{ab}}$ & $7.43 \pm 0.53$ & $7.57 \pm 0.79^{\mathrm{b}}$ & $7.62 \pm 0.76$ \\
\hline & 12 & $7.14 \pm 0.38^{\mathrm{ab}}$ & $7.29 \pm 0.49$ & $7.43 \pm 0.78^{\mathrm{b}}$ & $7.43 \pm 0.79$ \\
\hline & 15 & $7.00 \pm 0.82^{\mathrm{b}}$ & $7.14 \pm 0.69$ & $7.43 \pm 0.53^{\mathrm{b}}$ & $7.29 \pm 0.49$ \\
\hline \multirow{6}{*}{ Flavor } & 0 & $8.23 \pm 0.90^{\mathrm{a}}$ & $8.29 \pm 0.95^{\mathrm{a}}$ & $8.36 \pm 0.76^{\mathrm{a}}$ & $8.03 \pm 0.58^{\mathrm{a}}$ \\
\hline & 3 & $8.14 \pm 0.69^{\mathrm{a}}$ & $8.08 \pm 0.69^{\mathrm{ab}}$ & $8.29 \pm 0.52^{\mathrm{a}}$ & $8.00 \pm 0.82^{\mathrm{a}}$ \\
\hline & 6 & $7.86 \pm 0.38^{\mathrm{a}}$ & $7.71 \pm 0.49^{\mathrm{ab}}$ & $7.86 \pm 0.69^{\mathrm{ab}}$ & $7.38 \pm 0.76^{\mathrm{ab}}$ \\
\hline & 9 & $7.43 \pm 0.53^{\mathrm{ab}}$ & $7.43 \pm 0.53^{\text {bc }}$ & $7.57 \pm 0.53^{\mathrm{ab}}$ & $7.29 \pm 0.55^{\mathrm{ab}}$ \\
\hline & 12 & $6.71 \pm 0.76^{\mathrm{bc}}$ & $6.71 \pm 0.76^{\mathrm{cd}}$ & $7.14 \pm 0.38^{\mathrm{bc}}$ & $6.57 \pm 0.79^{\mathrm{bc}}$ \\
\hline & 15 & $6.00 \pm 0.58^{\mathrm{c}}$ & $6.00 \pm 0.58^{\mathrm{d}}$ & $6.57 \pm 0.98^{c}$ & $6.14 \pm 0.69^{c}$ \\
\hline \multirow{6}{*}{ Tenderness } & 0 & $7.50 \pm 0.84^{\mathrm{Ba}}$ & $7.92 \pm 0.49^{\mathrm{ABa}}$ & $8.67 \pm 0.82^{\mathrm{Aa}}$ & $8.75 \pm 0.76^{\mathrm{Aa}}$ \\
\hline & 3 & $7.33 \pm 0.52^{\mathrm{Bab}}$ & $8.00 \pm 0.32^{\mathrm{Aa}}$ & $8.50 \pm 0.55^{\mathrm{Aab}}$ & $8.42 \pm 0.49^{\mathrm{Aab}}$ \\
\hline & 6 & $7.17 \pm 0.41^{\mathrm{Bab}}$ & $7.83 \pm 0.75^{\mathrm{ABa}}$ & $8.00 \pm 0.89^{\mathrm{ABabc}}$ & $8.25 \pm 0.52^{\mathrm{Aab}}$ \\
\hline & 9 & $6.75 \pm 0.42^{\mathrm{Bbc}}$ & $7.58 \pm 0.49^{\mathrm{Aab}}$ & $7.92 \pm 0.49^{\mathrm{Aabc}}$ & $7.92 \pm 0.38^{\mathrm{Abc}}$ \\
\hline & 12 & $6.25 \pm 0.69^{\mathrm{Bc}}$ & $6.92 \pm 1.28^{\mathrm{ABbc}}$ & $7.75 \pm 0.52^{\mathrm{Abc}}$ & $7.42 \pm 0.58^{\mathrm{Ac}}$ \\
\hline & 15 & $5.08 \pm 0.49^{\mathrm{Cd}}$ & $6.42 \pm 0.49^{\mathrm{Bc}}$ & $7.50 \pm 0.55^{\mathrm{Ac}}$ & $7.47 \pm 0.67^{\mathrm{Ac}}$ \\
\hline \multirow{6}{*}{ Juiciness } & 0 & $8.25 \pm 0.76^{\mathrm{Bab}}$ & $8.50 \pm 0.55^{\mathrm{ABab}}$ & $9.33 \pm 0.52^{\mathrm{Aab}}$ & $9.33 \pm 0.82^{\mathrm{Aa}}$ \\
\hline & 3 & $8.00 \pm 0.63^{\mathrm{Ba}}$ & $8.67 \pm 0.52^{\mathrm{ABa}}$ & $9.17 \pm 0.75^{\mathrm{Aa}}$ & $9.00 \pm 0.63^{\mathrm{Aa}}$ \\
\hline & 6 & $7.33 \pm 1.03^{\mathrm{Bab}}$ & $8.17 \pm 0.98^{\mathrm{ABab}}$ & $8.67 \pm 0.52^{\mathrm{Aab}}$ & $8.83 \pm 0.75^{\mathrm{Aa}}$ \\
\hline & 9 & $7.42 \pm 0.80^{\mathrm{Bab}}$ & $7.58 \pm 0.49^{\mathrm{Bbc}}$ & $8.42 \pm 0.49^{\mathrm{Aab}}$ & $8.17 \pm 0.68^{\mathrm{ABab}}$ \\
\hline & 12 & $6.50 \pm 0.84^{\mathrm{Bbc}}$ & $6.75 \pm 0.61^{\mathrm{Bc}}$ & $8.00 \pm 0.55^{\mathrm{Ab}}$ & $8.08 \pm 0.80^{\mathrm{Aab}}$ \\
\hline & 15 & $6.17 \pm 0.75^{\mathrm{Bc}}$ & $6.92 \pm 0.80^{\mathrm{ABc}}$ & $7.83 \pm 0.75^{\mathrm{Ab}}$ & $7.67 \pm 0.61^{\mathrm{Ab}}$ \\
\hline \multirow{6}{*}{$\begin{array}{c}\text { Overall } \\
\text { acceptability }\end{array}$} & 0 & $8.42 \pm 0.80^{\mathrm{Ba}}$ & $8.67 \pm 0.52^{\mathrm{Ba}}$ & $9.42 \pm 0.49^{\mathrm{Aa}}$ & $9.50 \pm 0.55^{\mathrm{Aa}}$ \\
\hline & 3 & $7.92 \pm 0.20^{\mathrm{Bab}}$ & $8.83 \pm 0.75^{\mathrm{ABa}}$ & $9.17 \pm 0.98^{\mathrm{Aa}}$ & $9.00 \pm 0.89^{\mathrm{Aab}}$ \\
\hline & 6 & $7.50 \pm 0.55^{\mathrm{Bbc}}$ & $8.67 \pm 1.03^{\mathrm{Aa}}$ & $8.83 \pm 0.41^{\text {Aab }}$ & $8.67 \pm 0.82^{\text {Aab }}$ \\
\hline & 9 & $7.42 \pm 0.49^{\mathrm{Bbc}}$ & $7.92 \pm 0.49^{\mathrm{ABa}}$ & $8.50 \pm 0.55^{\mathrm{Aab}}$ & $8.58 \pm 0.66^{\mathrm{Aab}}$ \\
\hline & 12 & $6.83 \pm 0.41^{\mathrm{Bc}}$ & $6.92 \pm 0.80^{\mathrm{Bb}}$ & $8.17 \pm 0.68^{\mathrm{Ab}}$ & $8.33 \pm 0.82^{\mathrm{Abc}}$ \\
\hline & 15 & $5.83 \pm 0.75^{\mathrm{Bd}}$ & $6.58 \pm 1.11^{\mathrm{ABd}}$ & $7.17 \pm 0.98^{\mathrm{Ac}}$ & $7.58 \pm 0.49^{\mathrm{Ac}}$ \\
\hline
\end{tabular}

All values are mean \pm SD.

${ }^{A-C}$ Means in the same row with different letters are significantly different $(p<0.05)$.

${ }^{\mathrm{a}-\mathrm{d}}$ Means in the same column with different letters are significantly different $(p<0.05)$.

${ }^{1)}$ Treatments: T1, ground pork added with $1 \%$ rice bran fiber; T2, ground pork added with $2 \%$ rice bran fiber; T3, ground pork added with $3 \%$ rice bran fiber

the storage period of $15 \mathrm{~d}$. Meanwhile, antioxidative properties of treatments with rice bran fiber were determined to be low compared with control. Therefore, our results suggest that the addition of rice bran fiber is effective in maintaining the physicochemical properties, and the combined addition of useful antioxidants with rice bran fiber may be an effective strategy for maintaining the quality characteristics of meat products during cold storage.

\section{Acknowledgements}

This research was supported by the Rural Development
Administration (033-006-001-01-00). The authors were supported by the Brain Korean 21 (BK 21) Project from Ministry of Education and Human Resources Development.

\section{References}

1. Aleson-Carbonell, L., Fernández-López, J., Pérez-Alvarez, J. A., and Kuri, V. (2005) Characteristics of beef burger as influenced by various types of lemon albedo. Innovat. Food Sci. Emerg. Tech. 6, 247-255.

2. Andrés, S. C., García, M. E., Zaritzky, N. E., and Califano, A. N. (2006) Storage stability of low-fat chicken sausages. $J$. Food Eng. 72, 311-319. 
3. Ang, C. Y. W. and Huang, Y. W. (1994) Color change of chicken leg patties due to end-point temperature, packaging and refrigerated storage. J. Food Sci. 59, 26-29.

4. Candogan, K. and Kolsarici, N. (2003) The effects of carrageenan and pectin on some quality characteristics of low-fat beef frankfurters. Meat Sci. 64, 199-206.

5. Choi, Y. S., Choi, J. H., Han, D. J., Kim, H. Y., Lee, M. A., Kim, H. W., Jeong, J. Y., Paik, H. D., and Kim, C. J. (2008) Effect of adding levels of rice bran fiber on the quality characteristics of ground pork meat product. Korean J. Food Sci. Ani. Resour. 28, 319-326.

6. Choi, Y. S., Choi, J. H., Han, D. J., Kim, H. Y., Lee, M. A., Kim, H. W., Lee, J. W., Chung, H. J., and Kim, C. J. (2010) Optimization of replacing pork back fat with grape seed oil and rice bran fiber for reduced-fat meat emulsion systems. Meat Sci. 84, 212-218.

7. Choi, Y. S., Choi, J. H., Han, D. J., Kim, H. Y., Lee, M. A., Kim, H. W., Jeong, J. Y., and Kim, C. J. (2009) Characteristics of low-fat meat emulsion system with pork fat replaced by vegetable oils and rice bran fiber. Meat Sci. 82, 266-271.

8. Choi, Y. S., Choi, J. H., Han, D. J., Kim, H. Y., Lee, M. A., Kim, H. W., Jeong, J. Y., and Kim, C. J. (2011) Effects of rice bran fiber on heat-induced gel prepared with pork salt-soluble meat proteins in model system. Meat Sci. 88, 59-66.

9. Davies, A. and Board, R. (1998) The microbiology of meat and poultry. Blackie Academic \& Professional, London, UK, pp. 288.

10. Demeyer, D. I. and Vanderkerchhove, P. (1979) Compounds determining $\mathrm{pH}$ in dry sausage. Meat Sci. 3, 161-165.

11. Field, R. A. and Chang, Y. D. (1969) Free amino acids in bovine muscle and their relationship to tenderness. J. Food Sci. 34, 329-331.

12. Flores, M., Moya, V. J., Aristoy, M. C., and Toldrá, F. (2000) Nitrogen compounds as potential biochemical marker of pork meat quality. Food Chem. 69, 371-377.

13. Ganhão, R., Morcuende, D., and Estévez, M. (2010) Protein oxidation in emulsified cooked burger patties with added fruit extracts: Influence on colour and texture deterioration during chill storage. Meat Sci. 85, 402-409.

14. García, M. L., Dominguez, R., Galvez, M. D., Casas, C., and Selgas, M. D. (2002) Utilization of cereal and fruit fibres in low fat dry fermented sausages. Meat Sci. 60, 227-236.

15. Herrero, A. M., Ordóñez, J. A., de Avila, M. D. R., Herranz, B., De la Hoz, L., and Cambero, M. I. (2007) Breaking strength of dry fermented sausages and their correlation with texture profile analysis (TPA) and physico-chemical characteristics. Meat Sci. 77, 331-338.

16. Huang, S. C., Shiau, C. Y., Liu, T. E., Chu, C. L., and Hwang, D. F. (2005) Effects of rice bran on sensory and physicochemical properties of emulsified pork meatballs. Meat Sci. 70, 613-619.

17. Hutchings, J. B. (1999) Food color and appearance. Aspen Publishers Inc., Maryland, pp. 453-541.

18. Jimenez Colmenero, F. (2000) Relevant factors in strategies for fat reduction in meat products. Trends Food Sci. Technol. 11, 56-66.
19. Jones, R. P. and Rogers, R. W. (1971) Effect of shelf temperatures, storage periods and rehydration solution on the acceptability and chemical composition of free-dried precooked commercially cured ham. J. Anim. Sci. 32, 624-627.

20. Kang, S. N., Jang. A., Lee, S. O., Min, J. S., and Lee, M. (2002) Effect of organic acid on value of VBN, TBARS, color and sensory property of pork meat. Korean J. Anim. Sci. Technol. 44, 443-452.

21. Kauffman, R. G., Eikelenboom, G., Vander Wal, P. G., Engel, B., and Zaar, M. (1986) A comparison of methods to estimate water holding capacity in post-rigor porcine muscle. Meat Sci. 18, 307-322.

22. Kim, I. S., Jin, S. K., Nam, S. H., Nam, Y. W., Yang, M. R., Min, H, S., and Kim, D. H. (2008) Effect of hot-air dried tomato powder on the quality properties of pork patties during cold storage. Korean J. Anim. Sci. Techol. 50, 225-264.

23. Lee, H. J. and Shin, M. S. (2006) Quality characteristics of french bread with various dietary fibers. Korean J. Food Cookery Sci. 22, 477-487.

24. Lim, B. O., Lee, C. J., and Kim, J. D. (2004) Study on immunoregulatory function of dietary fiber. Food Industry Nutr. 9, 26-30.

25. Park, K. Y., Kan, C. S., Cho, Y. C., Lee, Y. S., Lee, Y. H., and Lee, Y. S. (2003) Genotypic difference in tocopherol and tocotrienol contents of rice bran. Korean J. Crop Sci. 48, 469-472.

26. Pearson, A. M. and Young, R. B. (1989) Muscle and Meat Biochemistry. Academic press, San Diego, CA, pp. 1-261.

27. Pearson, D. (1968) Assesment of meat freshness in quality control employing chemical techniques. A review. J. Food Sci. 19, 357-363.

28. Phillips, A. L., Faustman, C., Lynch, M. P., Govoni, K. E., Hoagland, T. A., and Zinn, S. A. (2001) Effect of dietary $\alpha$ tocopherol supplementation on color and lipid stability in pork. Meat Sci. 58, 389-393.

29. SAS (1999) SAS/STAT Software for PC. Release 8.1, SAS Institute Inc., Cary, NC, USA.

30. Suh, K. D. (1984) The production of boneless ham and the role of additives in processing. Korean Soc. Meat Technol. 5, 41.

31. Tarladgis, B. G., Watts, B. M., Younathanm, M. T., and Dugan, L. (1960) A distillation method for the quantitative determination of malonaldehyde in rancid foods. J. Am. Oil Chem. Soc. 37, 44-52.

32. Thebaudin, J. Y., Lefebvre, A. C., Harrington, M., and Bourgeois, C. M. (1997) Dietary fibres: Nutritional and technological interest. Trends Food Sci. Technol. 8, 41-48.

33. Turner, E. W., Paynter, W. D., Mountie, E. J., Bessert, M. W., Struck, G. M., and Olson, F. C. (1954) Use of the 2-thiobarbituric acid reagent to measure rancidity in frozen pork. Food Technol. 8, 327-333.

34. Vaithiyanathan, S., Naveena, B. M., Muthukumar, M., Girish, P. S., and Kondaiah, N. (2011) Effect of dipping in pomegranate (Punica granatum) fruit juice phenolic solution on the shelf life of chicken meat under refrigerated storage (4 $\left.{ }^{\circ} \mathrm{C}\right)$. Meat Sci. 88, 409-414. 
35. Woo, K. M., Lee, Y. S., and Kim, Y. H. (2005) Antioxidant effects of tocotrienol in rice bran. Korean J. Crop Sci. 50, 47.

36. Yang, A., Brewster, M. J., Lanari, M. C., and Tume, R. K. (2002) Effect of vitamin E supplementation on $\alpha$-tocopherol and $\beta$-carotene concentrations in tissues from pasture- and grain-fed cattle. Meat Sci. 60, 35-40.

37. Yilmaz, I. (2004) Effects of rye bran addition on fatty acid composition and quality characteristics of low-fat meatball. Meat Sci. 67, 245-249.

38. Yilmaz, I. (2005) Physicochemical and sensory characteris- tics of low fat meatballs with added wheat bran. J. Food Eng. 69, 369-373.

39. Yilmaz, I. and Dağlioğlu, O. (2003) The effect of replacing fat with oat bran on fatty acid composition and physicochemical properties of meatballs. Meat Sci. 65, 819-823.

40. Youssef, M. K. and Barbut, S. (2011) Fat reduction in comminuted meat products-effects of beef fat, regular and preemulsified canola oil. Meat Sci. 87, 356-360.

$\overline{\text { (Received 2011.1.21/Revised 2011.3.17/Accepted 2011.3.18) }}$ 